Article

\title{
Soil Nitrogen and Weed Biodiversity: An Assessment under Two Orchard Floor Management Practices in a Nitrogen Vulnerable Zone in Italy
}

\author{
Md Jebu Mia ${ }^{1}$ (D) Elga Monaci ${ }^{1}$, Giorgio Murri ${ }^{2}$, Francesca Massetani ${ }^{3}$, Jacopo Facchi ${ }^{3}$ \\ and Davide Neri ${ }^{1, *(D)}$ \\ 1 Dipartimento di Scienze Agrarie, Alimentari ed Ambientali, Università Politecnica delle Marche, \\ Via Brecce Bianche, 60131 Ancona, Italy; m.j.mia@pm.univpm.it (M.J.M.) e.monaci@staff.univpm.it (E.M.) \\ 2 Azienda Agraria Didattico Sperimentale, Università Politecnica delle Marche, Via Brecce Bianche, \\ 60131 Ancona, Italy; g.murri@univpm.it \\ 3 HORT Soc. Coop., Via Cardeto n.70, 60121 Ancona, Italy; f.massetani@hort.it (F.M.); j.facchi@hort.it (J.F.) \\ * Correspondence: d.neri@staff.univpm.it; Tel.: +39-3408603377
}

Received: 16 October 2020; Accepted: 2 December 2020; Published: 7 December 2020

\begin{abstract}
Nowadays, understory vegetation along the tree row is considered a vital source of agroecosystem services and functional biodiversity improvement in the fruit orchard. Hence, current orchard floor management systems encourage practicing a more sustainable approach that supports vegetation cover rather than keeping bare soil herbicide use, or tillage. A two-year field trial was conducted using two different ground management techniques; integrated mowing (mower and brush or disc) and herbicide (glyphosate) in two commercial apple and peach orchards in a nitrogen vulnerable zone (NVZ) of the Marche region, Italy. This study aimed to evaluate the effects of these practices on soil N status, weed abundance, percent of soil cover, and dry weed biomass production. Weed management systems had no significant effect on soil organic matter and $\mathrm{N}$ availability; however, an improvement was noticed under integrated mowing when compared to the one treated with herbicides. Integrated mowing had a significant effect on species richness, soil coverage, and weed biomass production, which was approximately 2-times higher than in the herbicide-treated plots. The overall results showed that integrated mowing maintained a balance in the soil $\mathrm{N}$ status of both orchards, while supporting above-ground weed biodiversity and soil protection.
\end{abstract}

Keywords: soil management; nitrogen fertility; integrated mowing; herbicide; weed biodiversity

\section{Introduction}

Conventional weed management along the tree row in a fruit orchard relies heavily on herbicide use, which is applied during the production season to suppress ground vegetation, causing desiccation and death of herbaceous plants and roots. Herbicides can control weed competition effectively, although they leave chemical residues in the soil which decrease soil fertility and orchard biodiversity [1,2]. We concede that such an approach may become a serious threat to environmental sustainability in the long run. A continuous application of herbicides results in augmenting soil erosion, diminishing soil organic matter content, and microbial activity, while impairing soil nutrients status due to the alteration of net $\mathrm{N}$ mineralization [3]. Herbicides may also disturb natural nutrient decomposition in the soil by interacting with earthworms, fungi, and bacteria [4]. However, soil quality and biodiversity can be restored by practicing more sustainable weed management techniques that maintain the soil covered with spontaneous vegetation $[5,6]$. Above ground vegetation can deliver several ecosystem services including environmental protection [7], habitat for beneficial microorganism [8], as well as sustaining soil fertility by hosting mycorrhizae [9]. These improve soil organic matter content, aggregates stability, 
biological activity, and nutrient cycles [4,10], through an accumulation of above ground biomass, root exudates, and other organic compounds into the soil. Thus, they ameliorate overall soil quality by accelerating the humification process [6] while increasing plant biodiversity and natural antagonists of crop pests and diseases [11]. These benefits can be even more important for the growth of fruit trees because the 'niche effect' of having a part of their root system in optimal allelopathic condition can enhance resilience in the orchard, while reducing the self-residue impact [12-14].

Valdaso is the most important fruit production area in the Marche region (Italy) due to the historical presence of a high number of specialized fruit growers. Smallholder intensive farming systems dominate the Valdaso agricultural landscape, which is recognized to be a nitrate vulnerable zone (NVZ) [15]. Recently, contamination of soil and aquifers has become a serious concern for the fruit growers, due to excess nitrate leaching, and consequent contamination of water bodies in the area [16]. However, maintaining ground vegetation along the tree row can be a viable solution for these problems, because plants are capable of absorbing $\mathrm{N}$ from the soil throughout their cycle, while sequestering it in their tissues. Thus, they can deliver $\mathrm{N}$ into the soil during the process of decomposition $[17,18]$. For this reason, an eradication of understory vegetation along the trees row is not desirable in sustainable orchard floor management [19]. Managing orchard floors with living vegetation is a good agricultural practice to reduce the risk of potential leaching of nitrates [16]. The European Union (EU) introduced agri-environmental measures (AEMs) to support farmers and reduce the environmental risks in sustainable rural development [20]. Therefore, a more ecological approach is highly recommended, particularly in vulnerable agricultural areas like Valdaso where small land holders operate high-input and low-efficiency fruit production systems [21].

In high density orchards, fruit yields and quality are controlled primarily by soil and nutritional management. Fruit growers prefer a more sustainable approach for sustaining soil fertility with greater nutrients and water availability, in an attempt to reduce competition between understory vegetation and fruit trees, while striving for increasing biodiversity, orchard resilience, and reducing risks of soil sickness $[13,22]$. Ground cover management can be accomplished through a broad use of different techniques that impact soil nutritional status and plant biodiversity in different ways. Effective weed management has to be done to balance $\mathrm{N}$ availability, since too little $\mathrm{N}$ results in lower crop productivity. On the other hand, too much $\mathrm{N}$ leads to environmental pollution and its concomitant threats to ecosystems' health and functioning [23]. Therefore, an integrated mowing system was developed for sustainable orchard management with two advanced tools: a rotary brush weeder and a mower, where the rotary brush weeder facilitates bending the weed plant stems close to the tree trunk, avoiding any trunk damage. At the same time, mowing the weeds does not disturb the soil, and it deposits the mowed residues in the soil surface along the row $[19,24]$. Eventually, they are used as mulching materials, but in any case, ensure covered soil with spontaneous vegetation along the tree row.

In this study, we compared an integrated mechanical mowing system (mower with brush or disc) with a standard herbicide (glyphosate) application in two commercial fruit orchards (apple and peach). The aim of the study was to evaluate the effect of integrated mechanical weed management on soil quality parameters including soil nitrogen status and organic matter content, and on weed biodiversity, measurable as weed species number, percent of soil coverage, and weed biomass production.

\section{Materials and Methods}

\subsection{Site Descriptions, Research Design and Management Practices}

The study was conducted from 2018 to 2019 in two different commercial orchards at Valdaso in the Marche region (central Italy, $43^{\circ} 00^{\prime} 13.70^{\prime \prime} \mathrm{N}, 13^{\circ} 35^{\prime} 45.98^{\prime \prime} \mathrm{E}$ ). The region benefits from a warm and temperate climate, with the average annual temperature and precipitation of $15.4{ }^{\circ} \mathrm{C}$ and $794 \mathrm{~mm}$, respectively (Figure 1). A three-year old apple (Malus $\times$ domestica Borkh., cv. Crimson Crisp; rootstock M9) orchard was established on a sandy clay loam (sand 55\% + silt $16.7 \%$ + clay $28.3 \%$, USDA 
classification) Holocene alluvial soil (soil service of Marche Region, Italy). It has 1.29\% organic matter, $0.14 \%$ total $\mathrm{N}$, with soil $\mathrm{pH}$, and $\mathrm{EC}$ of 8.25 (alkaline) and $0.75 \mathrm{mS} \mathrm{cm}^{-1}$, respectively. The trees were spaced at $4 \times 1 \mathrm{~m}$ (2500 trees/ha), trained to a spindle system, and covered with a white high-density polyethylene net to protect them from insects and hailstorms. The second study site had a three year-old peach (Prunus persica L. Batsch cv. Royal Sweet; rootstock GF677) orchard, located adjacent to the apple farm. Peach trees were planted at the distance of $4 \times 3 \mathrm{~m}$ ( 833 trees/ha) between row to row and plant to plant. The soil was classified as above: sandy clay loam (sand $46.7 \%+$ silt $26.7 \%$ + clay $26.7 \%$ ) with a soil organic matter, total $\mathrm{N}$, soil pH, and EC of $1.16 \%, 0.09 \%, 8.04$ (alkaline), and $1.21 \mathrm{mS} \mathrm{cm}^{-1}$, respectively. The trees were trained to a palmette system.

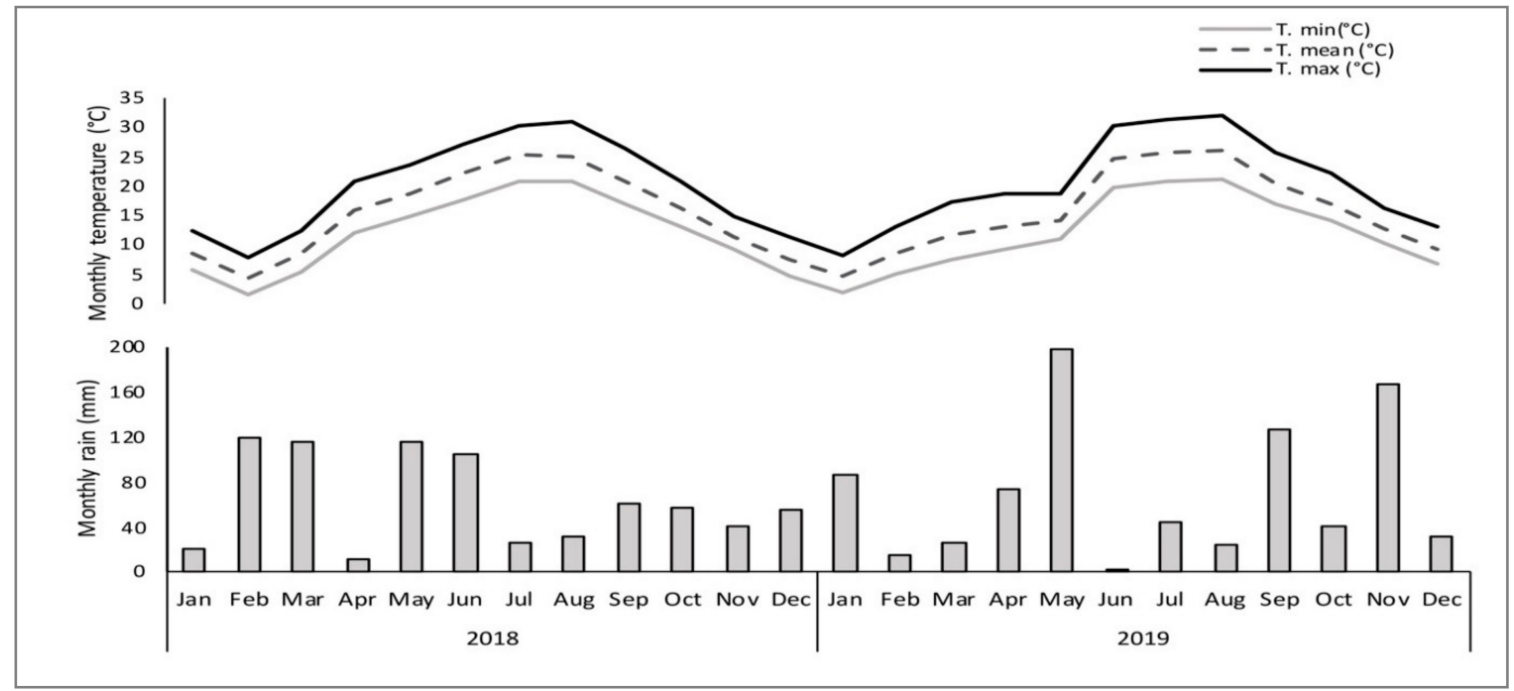

Figure 1. Monthly rain (mm.), minimum/maximum and mean temperature $\left({ }^{\circ} \mathrm{C}\right)$ measured during the experiment (2018-2019) with a meteorological station located $3 \mathrm{~km}$ from the experimental field (Sistema Informativo Regionale Meteo-Idro-Pluviometrico, Marche, Italy).

In this study, two different weed management approaches were used; (1) Integrated mowing (mower with polypropylene brush mounted on a horizontal axis or disc, Falconero Group S.R.L company, Faenza, Italy), and (2) Herbicide (mixing $1 \mathrm{~L}$ glyphosate - $360 \mathrm{~g} / \mathrm{L}$ acid equivalent Fandango, Monsanto Agricoltura, Italy-with $100 \mathrm{~L}$ of water, for 0.25 ha sprayed surface area, with a total applied dose of $4.0 \mathrm{~L} / \mathrm{ha}$, where the amount of acid equivalent was $1.4 \mathrm{~kg} / \mathrm{ha}$ ). Herbicide was sprayed 2 times in each year while integrated mowing was applied 5 times in 2018 and 7 times in 2019. In both experimental sites, a randomized complete block design (RCBD) was laid out with three blocks and two treatments. Each treatment was replicated three times. Each replication was comprised of 32 trees for a total of 192 trees per species (6 replications $\times 32$ trees). Both orchards were drip irrigated in the summer and fertilized at an annual rate of $45 \mathrm{~kg} \mathrm{~N}, 48 \mathrm{~kg} \mathrm{P}, 75 \mathrm{~kg} \mathrm{~K}$, and $12.25 \mathrm{~kg}$ Ca per ha in apple, and $84.2 \mathrm{~kg} \mathrm{~N}, 51.4 \mathrm{~kg} \mathrm{P}$, and $164 \mathrm{~kg} \mathrm{~K}$ per ha in peach. For NPK fertilizer, different products such as DUNG 3.5.7s + 18C (Fomet, Italy), and YaraMila PARTNER (Yara, Italy) were used, while Neobit new (Cifo, Italy) was used as Ca fertilizer. The total amount of fertilizer was split in two application times (at the beginning of December, and mid-April) in apple and three times (at the beginning of December, mid-April, and June) in the peach orchard.

\subsection{Soil Samples and Analysis}

Soil samples were taken with an auger soil sampler at $0-20 \mathrm{~cm}$ and $20-40 \mathrm{~cm}$ from each replication of the treatment on 11 July and 24 September in 2018; 5 April, 26 July, and 10 October in 2019. A total of 60 samples for each treatment were collected over two years. The soil was air-dried and ground 
to pass through a $2 \mathrm{~mm}$ and $0.5 \mathrm{~mm}$ sieve before analysis. All roots and visible plant residues were removed by hand-picking. The soil samples were then stored at $4{ }^{\circ} \mathrm{C}$ in the refrigerator.

Soil oxidable organic carbon (SOC) was measured according to the Walkley and Black method, as described by Nelson and Sommers [25]. The soil organic matter (SOM) content was calculated by multiplying the determined organic carbon by 1.724 . Total nitrogen (TN) concentration was determined on air-dried soil, where subsamples of $20 \mathrm{mg}$ finely smashed soil were weighed in tin caps and analyzed with an elemental analyzer (CHNS-O Elemental Analyzer CE1110, ThermoQuest, Italy). Soil nitrate $\left(\mathrm{NO}_{3}{ }^{-}\right)$was extracted from $5 \mathrm{~g}$ of soil with a solution of $50 \mathrm{~mL}$ of $\mathrm{KCl}(0.01 \mathrm{M})$ [26]; the samples were agitated for $1 \mathrm{~h}$ followed by centrifugation, then the solutions were filtered and stored until analyzed through ion chromatography (Dionex ICS 1000, San Diego, CA, USA). Ammonium $\left(\mathrm{NH}_{4}{ }^{+}\right.$) was determined from $5 \mathrm{~g}$ of soil using a solution of $20 \mathrm{~mL}$ of $\mathrm{K}_{2} \mathrm{SO}_{4}(0.5 \mathrm{M})$; then samples were prepared by following the same agitation and centrifugation procedure as for soil nitrate solutions and analyzed according to the modified Berthelot method [26]. Soil mineral N (Nmin) was calculated as the sum of the amount of nitrate $\left(\mathrm{NO}_{3}{ }^{-}\right)$and ammonium $\left(\mathrm{NH}_{4}{ }^{+}\right)$, while soil organic $\mathrm{N}($ org $\mathrm{N}$ ) was determined by cutting off the total mineral $\mathrm{N}$ concentration from the total $\mathrm{N}$.

To measure the level of $\mathrm{NO}_{3}{ }^{-}$in the leached water, high end suction lysimeters (Irrometer company, Riverside, CA, USA) equipped with a tube (OD $22 \mathrm{~mm}$, ID $16 \mathrm{~mm}$, and wall $3 \mathrm{~mm}$ ) and a ceramic tip $(7 \mathrm{~cm})$ were installed at $15 \mathrm{~cm}$ and $45 \mathrm{~cm}$ soil depth, along the tree row in three replications in each of the treatments. They were installed to the respective depth by drilling the soil with an auger. A part of the removed soil was put back for the fixing of the lysimeters while adding the corresponding soil to each depth. Collections of the soil solutions were made using a manual pump (27 July and 24 September in 2018) and 25 May, 27 June, 26 July, and 10 October in 2019. The solution was removed from inside the lysimeters with a syringe attached to a hose. Thus, a total of 72 samples per each treatment were collected and stored in plastic test tube until analyzed by ion chromatography (Dionex ICS 1000, San Diego, CA, USA).

\subsection{Weed Biomass and Biodiversity Assessment}

Dry weed biomass production, weed species number, and percentage of soil coverage were considered as weed biodiversity variables in our study. Above ground weed biomass measurements were collected prior to a weed control event, during the summer season of each year (July-August), from three random locations per treatment, using a frame of $0.50 \mathrm{~m}^{2}(1 \mathrm{~m} \times 0.5 \mathrm{~m})$. Collected weed samples were placed in a separate paper bag before drying them in an oven at $65^{\circ} \mathrm{C}$ for $48 \mathrm{~h}$. Dry weed biomass was weighed using a digital balance. The measurements of species numbers and the percentage of soil cover along the tree row were estimated using the Braun-Blanquet method [27]. Visual weed ratings for each plot were recorded the day before the treatment application by randomly selecting $10 \mathrm{~m}^{2}(5 \mathrm{~m} \times 2 \mathrm{~m})$ area along the tree row. A total of 48 samples for each treatment were considered for all weed biodiversity parameters.

\subsection{Statistical Analysis}

A two-way analysis of variance (ANOVA) was the procedure employed for the data analysis. This considered four factors for soil data (orchard, treatment, soil depth, and sampling time) and three factors (orchard, treatment, and year) for weed biodiversity data. A one-way ANOVA was considered for the analysis of $\mathrm{NO}_{3}{ }^{-}$concentration in soil solutions. Significant differences were compared using mean separation with the Tukey-Kramer honestly significant difference (HSD) test $(p \leq 0.05)$. Statistical analysis was carried out with JMP Software (Release 8; SAS Institute Inc., Cary, NC, USA, 2009). 


\section{Results}

\subsection{Soil Organic Matter (SOM)}

Soil organic matter (SOM) did not differ significantly between the two treatments. However, it varied greatly, depending on the orchard, soil depth, and different sampling times (Table 1). Where SOM content was considerably higher in the apple orchard, at the upper soil surface $(0-20 \mathrm{~cm})$, in July 2018 and October 2019. However, no interaction effects were found among different factors.

Table 1. Two-way ANOVA for the effects of treatment, orchard, soil depth, sampling time, and their interactions on soil $\mathrm{N}$ variables and soil organic matter.

\begin{tabular}{|c|c|c|c|c|c|c|}
\hline Parameters & $\begin{array}{c}\mathrm{NO}_{3}^{-} \\
\left(\mathrm{mg} \mathrm{kg}^{-1}\right)\end{array}$ & $\begin{array}{c}\mathrm{NH}_{4}^{+} \\
\left(\mathrm{mg} \mathrm{kg}^{-1}\right)\end{array}$ & $\begin{array}{l}\text { Mineral N } \\
\left(\mathrm{mg} \mathrm{kg}^{-1}\right)\end{array}$ & $\begin{array}{c}\text { Organic N } \\
\left(\mathrm{g} \mathrm{kg}^{-1}\right)\end{array}$ & $\begin{array}{l}\text { Total N } \\
\left(\mathrm{g} \mathrm{kg}^{-1}\right)\end{array}$ & SOM (\%) \\
\hline \multicolumn{7}{|l|}{ Orchard (O) } \\
\hline Apple & 58.2 & 10.5 & 68.7 & $1.25 \mathrm{a}^{\mathrm{z}}$ & $1.32 \mathrm{a}$ & $1.62 \mathrm{a}$ \\
\hline Peach & 48.8 & 11.8 & 60.7 & $1.09 \mathrm{~b}$ & $1.15 \mathrm{~b}$ & $1.27 \mathrm{~b}$ \\
\hline$p$-value & 0.068 & 0.301 & 0.149 & 0.0001 & 0.0001 & 0.0001 \\
\hline \multicolumn{7}{|l|}{ Treatment (T) } \\
\hline Herbicide & 51.30 & 10.98 & 58.5 & 1.18 & 1.23 & 1.44 \\
\hline Integrated mowing & 55.75 & 11.31 & 62.8 & 1.17 & 1.24 & 1.45 \\
\hline$p$-value & 0.385 & 0.800 & 0.387 & 0.898 & 0.916 & 0.892 \\
\hline \multicolumn{7}{|l|}{ Soil depth (SD) } \\
\hline $0-20 \mathrm{~cm}$ & $67.68 \mathrm{a}$ & 12.51 & $75.3 \mathrm{a}$ & $1.26 \mathrm{a}$ & $1.34 \mathrm{a}$ & $1.61 \mathrm{a}$ \\
\hline $20-40 \mathrm{~cm}$ & $39.36 \mathrm{~b}$ & 9.78 & $46 \mathrm{~b}$ & $1.08 \mathrm{~b}$ & $1.13 \mathrm{~b}$ & $1.28 \mathrm{~b}$ \\
\hline$p$-value & 0.0001 & 0.407 & 0.0001 & 0.0001 & 0.0001 & 0.0001 \\
\hline \multicolumn{7}{|l|}{ Sampling time (ST) } \\
\hline 18 July & $37.7 \mathrm{bc}$ & $17.33 \mathrm{a}$ & $53.1 \mathrm{~b}$ & $1.13 \mathrm{~b}$ & $1.18 \mathrm{c}$ & $1.60 \mathrm{a}$ \\
\hline 18 September & $23.5 c$ & $8.95 b c$ & $24 \mathrm{c}$ & $0.98 c$ & $1.01 \mathrm{~d}$ & $1.32 \mathrm{~b}$ \\
\hline 19 April & $113.8 \mathrm{a}$ & $14.08 \mathrm{ab}$ & $148 \mathrm{a}$ & $1.18 \mathrm{~b}$ & $1.30 \mathrm{~b}$ & $1.24 \mathrm{~b}$ \\
\hline 19 July & $54.3 \mathrm{~b}$ & $6.75 c$ & $40.6 \mathrm{bc}$ & $1.38 \mathrm{a}$ & $1.44 \mathrm{a}$ & $1.46 \mathrm{ab}$ \\
\hline 19 October & $38.4 \mathrm{bc}$ & $8.62 \mathrm{bc}$ & $37.5 \mathrm{bc}$ & $1.19 \mathrm{~b}$ & $1.24 \mathrm{bc}$ & $1.60 \mathrm{a}$ \\
\hline$p$-value & 0.0001 & 0.0001 & 0.0001 & 0.0001 & 0.0001 & 0.0001 \\
\hline \multicolumn{7}{|l|}{ Interaction ( $p$-value) } \\
\hline $\mathrm{O} \times \mathrm{T}$ & 0.914 & 0.919 & 0.93 & 0.083 & 0.08 & 0.32 \\
\hline $\mathrm{O} \times \mathrm{SD}$ & 0.0001 & 0.544 & 0.78 & 0.834 & 0.55 & 0.85 \\
\hline $\mathrm{O} \times \mathrm{ST}$ & 0.0001 & 0.0333 & 0.0003 & 0.089 & 0.103 & 0.07 \\
\hline $\mathrm{T} \times \mathrm{SD}$ & 0.0622 & 0.199 & 0.0408 & 0.385 & 0.198 & 0.26 \\
\hline $\mathrm{T} \times \mathrm{ST}$ & 0.0306 & 0.995 & 0.0762 & 0.293 & 0.6250 & 0.86 \\
\hline $\mathrm{SD} \times \mathrm{ST}$ & 0.0001 & 0.442 & 0.0001 & 0.290 & 0.9017 & 0.68 \\
\hline $\mathrm{O} \times \mathrm{T} \times \mathrm{SD}$ & 0.40 & 0.1139 & 0.244 & 0.680 & 0.916 & 0.4313 \\
\hline $\mathrm{O} \times \mathrm{T} \times \mathrm{ST}$ & 0.4796 & 0.969 & 0.59 & 0.168 & 0.1820 & 0.194 \\
\hline $\mathrm{O} \times \mathrm{SD} \times \mathrm{ST}$ & 0.0001 & 0.994 & 0.0001 & 0.678 & 0.944 & 0.915 \\
\hline $\mathrm{T} \times \mathrm{SD} \times \mathrm{ST}$ & 0.08 & 0.203 & 0.185 & 0.964 & 0.96 & 0.88 \\
\hline $\mathrm{O} \times \mathrm{ST} \times \mathrm{SD} \times \mathrm{T}$ & 0.120 & 0.0884 & 0.095 & 0.928 & 0.955 & 0.91 \\
\hline
\end{tabular}

${ }^{\mathrm{z}}$ Means with the same letter in a column for each parameter are not significantly different at $p \leq 0.05$ (Tukey-Kramer HSD test).

\subsection{Soil Nitrogen Status}

Assessment of soil nitrogen availability is vital in the orchard, as fruit trees absorb $\mathrm{N}$ in both $\mathrm{NO}_{3}{ }^{-}$and $\mathrm{NH}_{4}{ }^{+}$forms [28]. Soil $\mathrm{NO}_{3}{ }^{-}$concentration did not differ between the weed management treatments, though integrated mowing plots showed the highest concentrations of $\mathrm{NO}_{3}{ }^{-}$than herbicide treated plots (Table 1). The apple orchard soil had a higher concentration of soil $\mathrm{NO}_{3}^{-}\left(58.2 \mathrm{mg} \mathrm{kg}^{-1}\right)$ than peach (48.8 $\mathrm{mg} \mathrm{kg}^{-1}$ ). Nevertheless, at 0-20 cm soil depth in April 2019, there was a higher soil $\mathrm{NO}_{3}{ }^{-}$when compared to $20-40 \mathrm{~cm}$ at other sampling times (Table 1, Figure 2). 


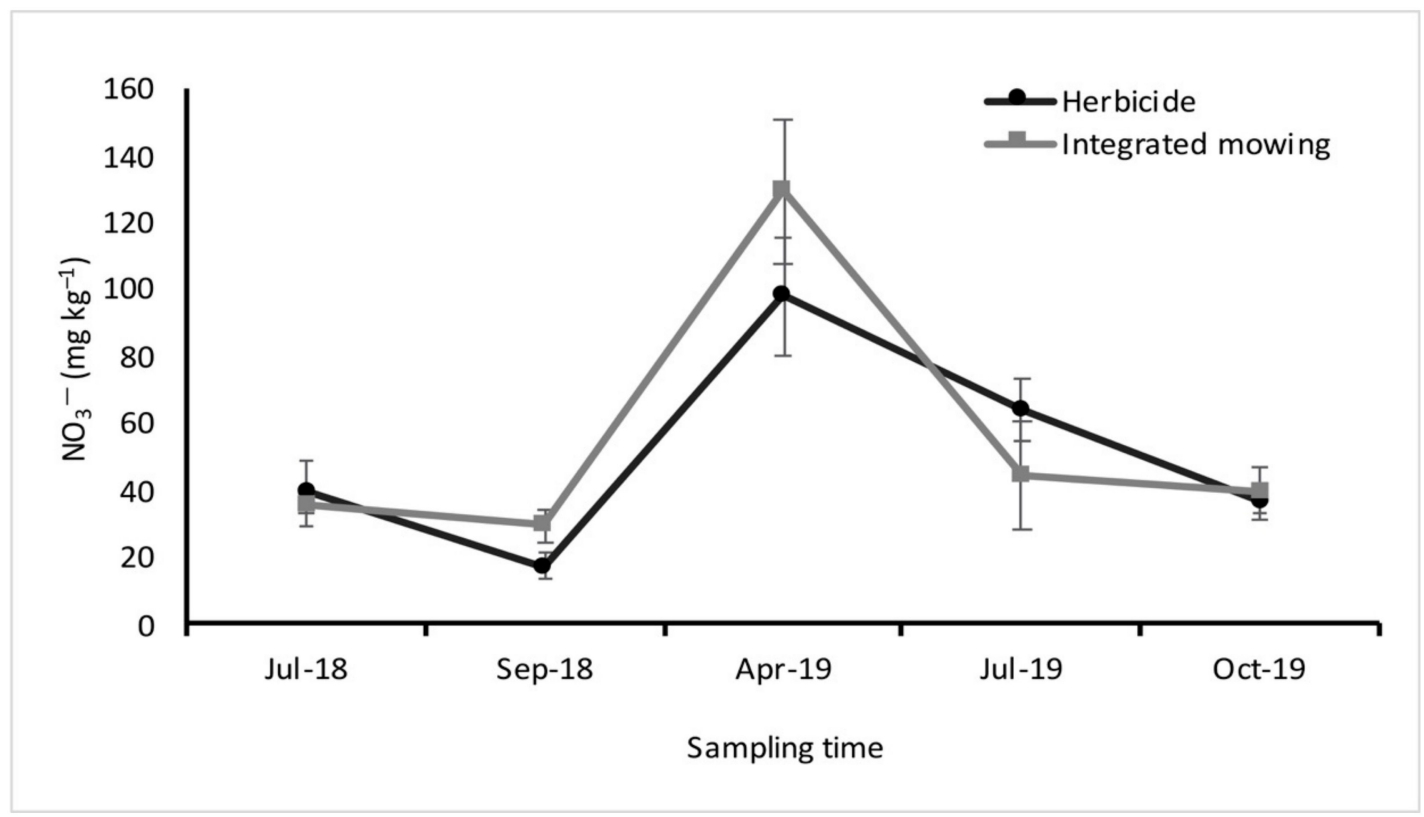

Figure 2. Interaction effects of treatment and sampling time on soil available $\mathrm{NO}_{3}{ }^{-}$in both apple and peach orchards. Bars represent the standard error.

The concentration of $\mathrm{NO}_{3}{ }^{-}$in the soil solution varied significantly between treatments, at different sampling times and soil depths (Table 1, Figure 3). Integrated mowing showed the highest $\mathrm{NO}_{3}{ }^{-}$ levels at $15 \mathrm{~cm}$ soil depth, at every sampling time, except May 2019, whereas under herbicide use, the highest $\mathrm{NO}_{3}{ }^{-}$values were measured at $45 \mathrm{~cm}$, excluding July 2018. However, only traces of $\mathrm{NO}_{3}{ }^{-}$ were detected in October 2019 under both treatments and soil depths.

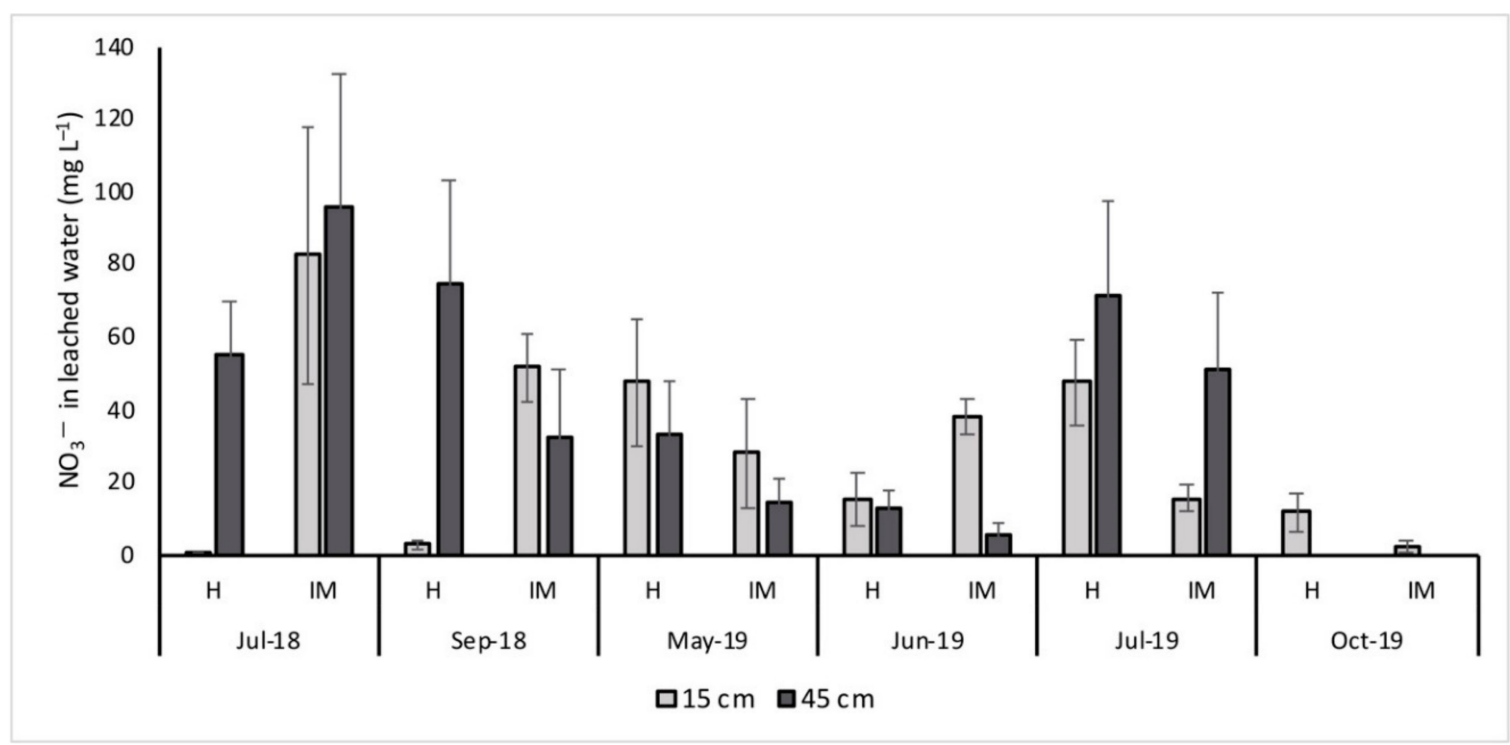

Figure 3. Treatment effect $(\mathrm{H}=$ herbicide and $\mathrm{IM}=$ integrated mowing $)$ on the concentration of $\mathrm{NO}_{3}{ }^{-}$ of leached water, in both apple and peach orchards. Bars represent the standard error.

These weed management approaches had a similar effect on ammonium $\left(\mathrm{NH}_{4}{ }^{+}\right)$concentrations in the soil, which averaged $11 \mathrm{mg} \mathrm{kg}^{-1}$ (Table 1). However, different sampling times showed that this $\mathrm{N}$ form $\left(\mathrm{NH}^{+}\right)$was higher $\left(17.3 \mathrm{mg} \mathrm{kg}^{-1}\right)$ in the sampling conducted in July 2018. In July 2019, the level of soil ammonium $\left(\mathrm{NH}_{4}{ }^{+}\right)$dropped to $6.75 \mathrm{mg} \mathrm{kg}^{-1}$. Such a situation might be due to the depletion of the oxidation process of $\mathrm{NH}_{4}{ }^{+}$into $\mathrm{NO}_{2}$, and eventually into $\mathrm{NO}_{3}{ }^{-}$, known as nitrification [29]. 
Overall, soil mineral nitrogen did not vary significantly between the two treatments (Table 1). Integrated mowing exhibited a little more mineral $\mathrm{N}$ value $\left(62.8 \mathrm{mg} \mathrm{kg}^{-1}\right)$ when compared to herbicide $\left(58.5 \mathrm{mg} \mathrm{kg}^{-1}\right)$. At $0-20 \mathrm{~cm}$ soil depth, the concentration of soil mineral $\mathrm{N}$ was higher at depths of 20-40 cm, where integrated mowing and herbicide demonstrated highest mineral $\mathrm{N}$ at upper and lower soil depth (Table 1, Figure 4). Among the sampling times, April 2019 revealed higher mineral N concentrations over others.

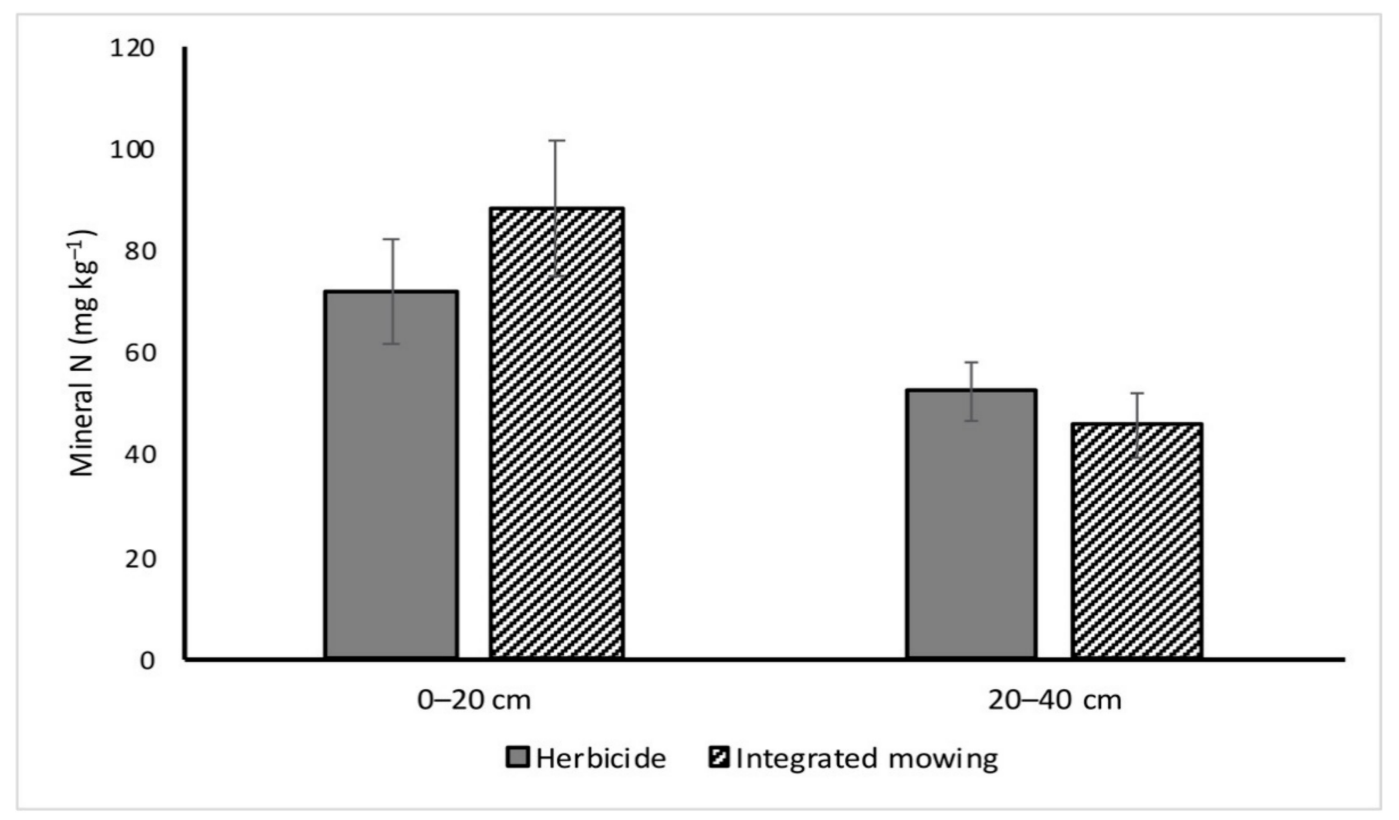

Figure 4. Interaction effects of treatment and soil depth on available mineral $\mathrm{N}$ in both apple and peach orchards. Bars represent the standard error.

Soil organic $\mathrm{N}$ was determined from total $\mathrm{N}$ after deducting of mineral $\mathrm{N}$ concentration. Both weed management methods showed a similar impact on soil organic $\mathrm{N}$ (Table 1). However, a significant effect was detected between two orchards, soil depth, and among different sampling times. For example, in the apple orchard, $12.8 \%$ higher organic $\mathrm{N}$ was produced than in the peach orchard. Again, upper soil layers $(0-20 \mathrm{~cm})$ had $14.3 \%$ more organic $\mathrm{N}$ than at $20-40 \mathrm{~cm}$. Data collected from July 2019 demonstrated a considerably higher amount of organic N compared to others, while September 2018 displayed a reduced level of organic $\mathrm{N}$.

Soil total $\mathrm{N}$ was highly affected by orchard soil, soil depth, and different sampling time, under two different weed management systems (Table 1). Apple orchard soil had higher total $\mathrm{N}$ content than peach soil, while upper soil layers possessed higher soil total $\mathrm{N}$ contents, throughout the experimental period. The concentration of total $\mathrm{N}$ in soil decreased with soil depth [30]. Among the sampling time, the highest total N was reached in July 2019, while the lowest in July 2018.

\subsection{Weed Biomass and Species Diversity}

Soil cover (\%) significantly differed between the treatments (Table 2). The integrated mowing plot maintained a higher percent of soil cover $(92.3 \%)$, which was 2 times higher than the herbicide treatment. No year effect was observed, but soil coverage increased $12.8 \%$ in 2019 , when compared to 2018. However, the apple orchard had a higher percent of vegetation coverage than the peach orchard.

Weed management practices had a significant effect on the number of weed species during the summer season of each year without differences among apple and peach orchards (Table 2). The results indicated that a substantial number of weed species were present in the integrated mowing plot, compared to the herbicide plot in each year without differences among apple and peach orchards 
(Figure 5). Nevertheless, weed species numbers were significantly reduced in the second year under both treatments.

Table 2. Two-way ANOVA for the effect of treatment, orchard, soil depth, sampling time, and their interactions on weed biodiversity parameters during the summer seasons in 2018-2019.

\begin{tabular}{cccc}
\hline Parameters & Soil Cover $(\%)$ & Weed Species Number $(\mathbf{n})$ & Dry Weed Biomass $\left(\mathrm{g} / \mathbf{m}^{\mathbf{2}}\right)$ \\
\hline Orchard (O) & & & \\
Apple & 68.3 & 4.9 & 97.0 \\
Peach & 56.9 & 4.2 & 95.2 \\
-value & 0.063 & 0.138 & 0.060 \\
\hline Treatment (T) & & & \\
Herbicide & $32.9 \mathrm{~b} \mathrm{Z}$ & $2.2 \mathrm{~b}$ & $55.5 \mathrm{~b}$ \\
Integrated mowing & $92.3 \mathrm{a}$ & $7.0 \mathrm{a}$ & $137 \mathrm{a}$ \\
p-value & 0.0001 & 0.0001 & 0.0001 \\
Year (Y) & & & $131.7 \mathrm{a}$ \\
2018 & 58.3 & $5.5 \mathrm{a}$ & $69.0 \mathrm{~b}$ \\
2019 & 66.9 & $3.7 \mathrm{~b}$ & 0.0001 \\
$p$-value & 0.1654 & 0.0004 & \\
\hline Interaction $(p$-value) & & & 0.438 \\
$\mathrm{O} \times \mathrm{T}$ & 0.972 & 0.381 & 0.0001 \\
$\mathrm{O} \times \mathrm{Y}$ & 0.040 & 0.019 & 0.988 \\
$\mathrm{~T} \times \mathrm{Y}$ & 0.396 & 0.930 & 0.264 \\
\hline
\end{tabular}

${ }^{\mathrm{Z}}$ Means with the same letter in a column for each parameter are not significantly different at $p \leq 0.05$ (Tukey-Kramer HSD test).
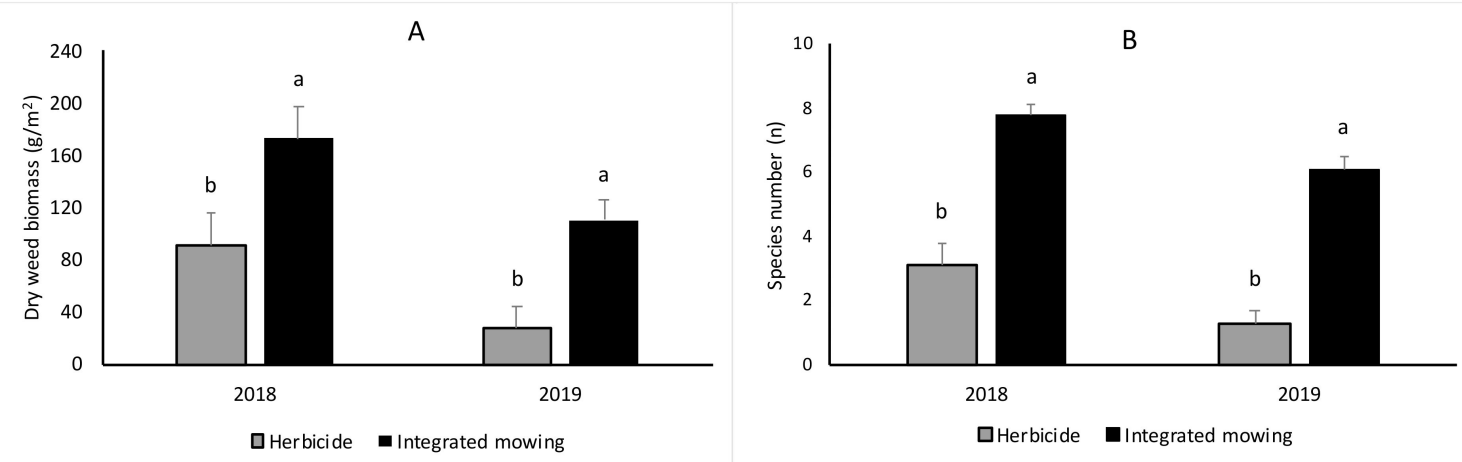

Figure 5. Effects of treatment on dry weed biomass (A) and species number (B) during the summer season. Bars represent standard error. Bars with different letters in a year are significantly different at $p$ $\leq 0.05$ (Tukey-Kramer HSD test).

A significantly higher above ground dry weed biomass during the summer season was recorded from integrated mowing plots $\left(137.0 \mathrm{~g} / \mathrm{m}^{2}\right)$, which indicates that the alternative treatment induced $59.5 \%$ more dry weed biomass compared to the herbicide system (Table 2). In the first year, weed biomass production was higher, but it decreased in the subsequent year. However, integrated mowing plots had significantly higher dry weed biomass in both years (Figure 5). Overall, both orchards yielded similar biomass production over two years.

\section{Discussion}

Nitrogen is essential for nutrition and growth of trees [31], and soil organic carbon is a fundamental indicator of soil quality [32], including ecological system evolution [33]. For this reason, this research emphasized soil organic matter content and nitrogen status assessment, especially as the area is recognized as NVZ. In addition, the climatic conditions of the study sites may have played a role in the 
mineralization of organic matter [24] and decomposition of plant residues [34], since temperature and rainfall distribution varied throughout the experimental period (Figure 1). However, no significant differences for soil organic matter were detected between soil management treatments and this is probably due to the short-term duration of the study and slow rate of change in behavior of organic matter content in the soil [35]. Nevertheless, soil organic matter content was slightly higher in the apple orchard where the percent of soil cover by the weed was higher, resulting in the integrated mowing plot response as we hypothesized. This outcome could be also the consequence of maintaining soil cover with vegetation and a deposition of mowed residues along the tree row, benefiting soil physical and chemical properties [36]. The upper soil layer $(0-20 \mathrm{~cm})$ always maintained a higher SOM under all treatment conditions. In addition to this, different sampling times demonstrated a significant effect on SOM content. In 2018, the value was higher in July, then decreased in September, which was followed by a low value in April 2019, while it increased again in July and in October 2019. Seasonal and climatic factors could be responsible for this kind of variation among sampling times. For example, $77.4 \mathrm{~mm}$ higher rainfall was recorded in 2019 than in 2018, while the average monthly temperature varied from 15.3 to $15.6{ }^{\circ} \mathrm{C}$ between years. Thus, these climatic fluctuations could be responsible for temporary changes of SOM by changing the overall oxidizing condition of soil at different sampling time. Mineral $\mathrm{N}$ is the key source of $\mathrm{N}$ for fruit trees; yet, it should be managed carefully to avoid risks of environmental pollution [30], especially when the trees are not absorbing nutrients from the soil (i.e., during the winter). For the management of soil mineral $\mathrm{N}$ in agroecosystems, the farmers are increasingly requesting for the development of an eco-friendly management system [37]. An assessment of mineral nitrogen can provide convincing evidence about available soil nitrogen [38], where soil $\mathrm{NO}_{3}{ }^{-}$and $\mathrm{NH}_{4}{ }^{+}$are the main forms. In this study, soil mineral $\mathrm{N}$ and $\mathrm{NO}_{3}{ }^{-}$concentrations showed the same patterns during the experiment, as described by Brunetto et al. [24]. Higher mineral $\mathrm{N}$ and $\mathrm{NO}_{3}{ }^{-}$concentrations were measured in the integrated mowing treatment compared to the herbicide (Table 1). In April 2019, the concentration of mineral N increased under both treatments (Figure 3) probably due to the effect of spring fertigation. In contrast, herbicide treatment showed lower $\mathrm{NO}_{3}{ }^{-}$ concentrations because of a higher leaching occurrence in the bare ground, than in vegetation covered soil $[24,39]$. The level of soil $\mathrm{NO}_{3}{ }^{-}$at depths of $20-40 \mathrm{~cm}$ increased in the herbicide plot when compared to mowing, while the opposite response was observed at 0-20 cm soil depth. However, lower mineral $\mathrm{N}$ and $\mathrm{NO}_{3}{ }^{-}$concentrations were detected in September 2018 and October 2019, and this could be due to the end of the growing season, when trees require less nutrients to maintain their physiological function. Our results revealed that the mineral $\mathrm{N}$ comprises of $80-85 \% \mathrm{NO}_{3}{ }^{-}$, while $\mathrm{NH}_{4}{ }^{+}$contributed only $15-20 \%$ in both orchards. Likewise, soil organic $\mathrm{N}$ and total $\mathrm{N}$ showed the same trend under all the variables considered in this study (Table 1). Additionally, $\mathrm{N}$ availability and SOM were higher in the apple orchard, integrated mowing plot, upper soil layer, and in July 2019. A significant difference between July 2018 and July 2019 sampling times was detected because of climatic fluctuations that had occurred during the two years. Our results showed a positive trend of total $\mathrm{N}$ content in the vegetative cover soil plot, managed by integrated mowing. However, $\mathrm{NO}_{3}{ }^{-}$concentration in leached water differed greatly among different sampling times, whereas maximum $\mathrm{NO}_{3}{ }^{-}$leaching occurred during July with a minimum in October. This could have been the result of greater availability of $\mathrm{NO}_{3}{ }^{-}$during the productive growing season of the trees than the off-season. In addition, the $\mathrm{NO}_{3}{ }^{-}$ concentration in leached water was higher in the deeper soil depths of the herbicide plot. Integrated mowing appeared to be able to limit $\mathrm{NO}_{3}{ }^{-}$leaching, which is not only crucial for healthy drinking water, but also for preserving the river water, within a vulnerable area (NVZ).

In sustainable orchard management systems, ground vegetations are considered as a source of enhancement of agroecosystem services and functional biodiversity [40,41]. The integrated mowing mimics a sustainable approach while supporting orchard biodiversity. This is crucial for diversifying residues which may buffer the presence of self-produced fruit crop residues [12]. Our results demonstrated that the integrated mowing technique maintained a significant percentage of soil coverage, species diversity, and dry weed biomass production in both orchards, which was approximately 2-times 
higher than in the herbicide system. This maintenance of covered soil using integrated mowing throughout the experimental period is advantageous for system sustainability, even though it needs to be controlled with repeated interventions to reduce the possible competition for water. In contrast, the soil remained bare in the herbicide plot, resulting in lower weed biodiversity, but it requires less weeding intervention and management cost [19]. It was worth noting that the year had a great effect on species diversity and weed biomass productions in both orchards (Table 2), and this could be due to the climatic variations and chemical residual effects. A total of 48 weed species were observed in both orchards over two years, where the total number of annual, perennial, and geophyte species were 30, 14, and 4, respectively [19]. The most dominant weed species in the integrated mowing and herbicide plots were perennial dandelion (Taraxacum officinale Weber) and annual birdeye speedwell (Veronica persica Poir.). However, a full list of weed species identified over two years can be found in our previous study by Mia et al. [19]. In 2019, the number of weed species was reduced in the apple but increased in the peach orchards, while an opposite result was obtained for weed biomass production. This response might have been due to the increased number of weeding interventions plus the short interval between two interventions during the summer season in peaches than in apple in 2019. This was probably because of the variation in other orchard management systems such as fertilizer application, supply of irrigation, and climatic conditions. For this reason, the apple orchard exhibited superior weed biodiversity than the peach orchard.

Fruit yield measured in our previous study [19] demonstrated comparable apple production between the two treatments, while the herbicide treatment showed a significantly higher fruit production in peach. In both orchards, various fruit quality attributes such as fruit firmness, soluble solids content (SSC), and dry matter content (DMC) responded more positively to the integrated mowing than herbicide. In addition, the higher costs involving integrated practices was covered by EU subsidy under the agro-environmental agreement (AEA) of Valdaso area, which supported this transition phase [19].

\section{Conclusions}

The findings of this study support the idea of maintaining vegetation coverage along the tree row. In comparison with herbicide-bare ground, the application of the integrated mowing technique (5-7 times per year) by combining the mower with a polypropylene brush or disc had no negative effect on overall soil $\mathrm{N}$ variables and organic matter content. Nitrate $\left(\mathrm{NO}_{3}{ }^{-}\right)$leaching was reduced considerably in leached water under the integrated mowing plot, which is of the utmost importance in a nitrogen vulnerable zone (NVZ). In addition, integrated mowing showed promising weed biodiversity (approximately 2-3 times higher than herbicide), including ground species number, percentage of soil coverage and aboveground dry weed biomass in both apple and peach orchards. In local agri-environmental agreements, government subsidies were given to the farmers to offset the additional costs needed for integrated technique. We believe that this study is the first step towards the possibility of supporting a balance of soil $\mathrm{N}$ and weed biodiversity in nitrogen vulnerable zone (NVZ) orchards in central Italy.

Author Contributions: Conceptualization, D.N.; Funding acquisition, G.M.; Investigation, M.J.M. and E.M.; Methodology, M.J.M., E.M., G.M., F.M. and J.F.; Supervision, D.N.; Writing—original draft, M.J.M.; Writing—review and editing, D.N. All authors have read and agreed to the published version of the manuscript.

Funding: The authors acknowledge the project "G.Eco.Valdaso-Gestione Ecocompatibile Accordo Agro-ambientale Valdaso" PSR Marche 2014-2020-16.2 for financial support.

Acknowledgments: The authors thank Azienda Agricola "Geminiani" and Azienda Agricola "Vagnoni" for providing information about the orchards and for hosting this research project and Nicola Lucci for the support.

Conflicts of Interest: The authors declare no conflict of interest. 


\section{References}

1. Geiger, F.; Bengtsson, J.; Berendse, F.; Weisser, W.W.; Emmerson, M.; Morales, M.B.; Ceryngier, P.; Liira, J.; Tscharntke, T.; Winqvist, C.; et al. Persistent negative effects of pesticides on biodiversity and biological control potential on European farmland. Basic Appl. Ecol. 2010, 11, 97-105. [CrossRef]

2. Mottes, C.; Lesueur-Jannoyer, M.; Bail, M.L.; Malézieux, E. Pesticide transfer models in crop and watershed systems: A review. Agron. Sustain. Dev. 2013, 34, 229-250. [CrossRef]

3. Zhang, Y.; Wang, L.; Yuan, Y.; Xu, J.; Tu, C.; Fisk, C.; Zhang, W.; Chen, X.; Ritchie, D.; Hu, S. Irrigation and weed control alter soil microbiology and nutrient availability in North Carolina Sandhill peach orchards. Sci. Total Environ. 2018, 615, 517-525. [CrossRef]

4. García-Pérez, J.; Alarcón-Gutiérrez, E.; Díaz-Fleischer, F. Interactive effect of glyphosate-based herbicides and organic soil layer thickness on growth and reproduction of the tropical earthworm Pontoscolex corethrurus (Müller, 1857). Appl. Soil Ecol. 2020, 155, 103648. [CrossRef]

5. Mia, J.; Massetani, F.; Murri, G.; Neri, D. Sustainable alternatives to chemicals for weed control in the orchard-A review. Hortic. Sci. 2020, 47, 1-12. [CrossRef]

6. Neri, D. Organic soil management to prevent soil sickness during integrated fruit production. IOBC WPRS Bull. 2013, 91, 87-99.

7. Granatstein, D.; Wiman, M.; Kirby, E.; Mullinix, K. Sustainability trade-offs in organic orchard floor management. Acta Hortic. 2010, 873, 115-122. [CrossRef]

8. Muscas, E.; Cocco, A.; Mercenaro, L.; Cabras, M.; Lentini, A.; Porqueddu, C.; Nieddu, G. Effects of vineyard floor cover crops on grapevine vigor, yield, and fruit quality, and the development of the vine mealybug under a Mediterranean climate. Agric. Ecosyst. Environ. 2017, 237, 203-212. [CrossRef]

9. Kubota, H.; Quideau, S.A.; Hucl, P.J.; Spaner, D. The effect of weeds on soil arbuscular mycorrhizal fungi and agronomic traits in spring wheat (Triticum aestivumL.) under organic management in Canada. Can. J. Plant Sci. 2015, 95, 615-627. [CrossRef]

10. Dignac, M.F.; Derrien, D.; Barré, P.; Barot, S.; Cécillon, L.; Chenu, C.; Chevallier, T.; Freschet, G.T.; Garnier, P.; Guenet, B.; et al. Increasing soil carbon storage: Mechanisms, effects of agricultural practices and proxies. A review. Agron. Sustain. Dev. 2017, 37, 14. [CrossRef]

11. Simon, S.; Jean-Charles, B.; Jean-François, D.; Benoît, S. Review article biodiversity and pest management in orchard systems. A review. Agron. Sustain. Dev. 2010, 30, 139-152. [CrossRef]

12. Giorgi, V.; Neri, D.; Lodolini, E.M.; Savini, G. Olea europaea L. root growth in soil patches with olive husks and hay residues. Int. J. Fruit Sci. 2008, 7, 19-32. [CrossRef]

13. Polverigiani, S.; Kelderer, M.; Neri, D. Growth of 'M9' apple root in five Central Europe replanted soils. Plant Root 2014, 8, 55-63. [CrossRef]

14. Endeshaw, S.T.; Lodolini, E.M.; Neri, D. Effects of olive shoot residues on shoot and root growth of potted olive plantlets. Sci. Hortic. 2015, 182, 31-40. [CrossRef]

15. Vanni, F. The agri-environmental agreement in valdaso (marche). In Agriculture and Public Goods; Springer: Dordrecht, The Netherlands, 2014; pp. 39-51. [CrossRef]

16. Cui, M.; Zeng, L.; Qin, W.; Feng, J. Measures for reducing nitrate leaching in orchards: A review. Environ. Pollut. 2020, 263, 114553. [CrossRef]

17. Atucha, A.; Merwin, I.A.; Brown, M.G. Long-term effects of four groundcover management systems in an apple orchard. HortScience 2011, 46, 1176-1183. [CrossRef]

18. Wang, N.; Wolf, J.; Zhang, F. Towards sustainable intensification of apple production in China-Yield gaps and nutrient use efficiency in apple farming systems. J. Integr. Agric. 2016, 15, 716-725. [CrossRef]

19. Mia, J.; Massetani, F.; Murri, G.; Facchi, J.; Monaci, E.; Amadio, L.; Neri, D. Integrated weed management in high density fruit orchards. Agronomy 2020, 10, 1492. [CrossRef]

20. Toderi, M.; Francioni, M.; Seddaiu, G.; Roggero, P.P.; Trozzo, L.; D’Ottavio, P. Bottom-up design process of agri-environmental measures at a landscape scale: Evidence from case studies on biodiversity conservation and water protection. Land Use Policy 2017, 68, 295-305. [CrossRef]

21. Cui, Z.; Zhang, H.; Chen, X.; Zhang, C.; Ma, W.; Huang, C.; Zhang, W.; Mi, G.; Miao, Y.; Li, X.; et al. Pursuing sustainable productivity with millions of smallholder farmers. Nat. Cell Biol. 2018, 555, 363-366. [CrossRef]

22. Polverigiani, S.; Franzina, M.; Neri, D. Effect of soil condition on apple root development and plant resilience in intensive orchards. Appl. Soil Ecol. 2018, 123, 787-792. [CrossRef] 
23. Zhang, X.; Davidson, E.A.; Mauzerall, D.L.; Searchinger, T.D.; Dumas, P.; Shen, Y. Managing nitrogen for sustainable development. Nat. Cell Biol. 2015, 528, 51-59. [CrossRef]

24. Brunetto, G.; Oliveira, B.S.; Ambrosini, V.G.; Couto, R.D.R.; Sete, P.B.; Junior, E.D.S.; Loss, A.; Oliveira-Stefanello, L.; Gatiboni, L.C. Nitrogen availability in an apple orchard with weed management. Ciência Rural 2018, 48. [CrossRef]

25. Nelson, D.W.; Sommers, L.E. Methods of Soil Analysis: Part 3 Chemical Methods; Book Series No.5; Soil Science Society of America: Madison, WI, USA, 1996; pp. 961-1010.

26. Mulvaney, R.L. Nitrogen-inorganic forms. SSSA Book Ser. 2018, 3, 1123-1184. [CrossRef]

27. Braun-Blanquet, J. Pflanzensoziologie; Springer: Berlin, Germany, 1928.

28. Zoppolo, R.J.; Stefanelli, D.; Bird, G.W.; Perry, R.L. Soil properties under different orchard floor management systems for organic apple production. Org. Agric. 2011, 1, 231-246. [CrossRef]

29. Wu, J.; Yan, G.; Zhou, G.; Xu, T. Model predictive control of biological nitrogen removal via partial nitrification at low carbon/nitrogen (C/N) ratio. J. Environ. Chem. Eng. 2014, 2, 1899-1906. [CrossRef]

30. Toselli, M.; Baldi, E.; Cavani, L.; Mazzon, M.; Quartieri, M.; Sorrenti, G.; Marzadori, C.; Moreno, T.; Elena, B.; Luciano, C.; et al. Soil-plant nitrogen pools in nectarine orchard in response to long-term compost application. Sci. Total Environ. 2019, 671, 10-18. [CrossRef]

31. Ge, S.F.; Xu, H.; Ji, M.; Jiang, Y.M. Characteristics of soil organic carbon, total nitrogen, and C/N ratio in Chinese apple orchards. Open J. Soil Sci. 2013, 3, 213-217. [CrossRef]

32. Granatstein, D.; Andrews, P.; Groff, A. Productivity, economics, and fruit and soil quality of weed management systems in commercial organic orchards in Washington State, USA. Org. Agric. 2014, 4, 197-207. [CrossRef]

33. Qiu, K.; Xie, Y.; Xu, D. Ecosystem functions including soil organic carbon, total nitrogen and available potassium are crucial for vegetation recovery. Sci Rep. 2018, 8, 7607. [CrossRef]

34. Leon, A.; Kohyama, K.; Takata, Y.; Yagi, K.; Umemiya, Y.; Ohkura, T.; Obara, H. Change in soil carbon in response to organic amendments in orchards and tea gardens in Japan. Geoderma 2015, 237, 168-175. [CrossRef]

35. Vance, E. Agricultural site productivity: Principles derived from long-term experiments and their implications for intensively managed forests. For. Ecol. Manag. 2000, 138, 369-396. [CrossRef]

36. Dabney, S.M.; Delgado, J.A.; Reeves, D.W. Using winter cover crops to improve soil and water quality. Commun. Soil Sci. Plant Anal. 2001, 32, 1221-1250. [CrossRef]

37. Carranca, C.; Brunetto, G.; Tagliavini, M. Nitrogen nutrition of fruit trees to reconcile productivity and environmental concerns. Plants 2018, 7, 4. [CrossRef] [PubMed]

38. Baldi, E.; Quartieri, M.; Muzzi, E.; Noferini, M.; Toselli, M. Use of in situ soil solution electric conductivity to evaluate mineral $\mathrm{N}$ in commercial orchards: Preliminary results. Horticulturae 2020, 6, 39. [CrossRef]

39. Ventura, M.; Scandellari, F.; Ventura, F.; Guzzon, B.; Pisa, P.R.; Tagliavini, M. Nitrogen balance and losses through drainage waters in an agricultural watershed of the Po Valley (Italy). Eur. J. Agron. 2008, 29, 108-115. [CrossRef]

40. Demestihas, C.; Plénet, D.; Génard, M.; Raynal, C.; Lescourret, F. Ecosystem services in orchards. A review. Agron. Sustain. Dev. 2017, 37, 12. [CrossRef]

41. Bàrberi, P.; Bocci, G.; Carlesi, S.; Armengot, L.; Blanco-Moreno, J.M.; Sans, F.X. Linking species traits to agroecosystem services: A functional analysis of weed communities. Weed Res. 2018, 58, 76-88. [CrossRef]

Publisher's Note: MDPI stays neutral with regard to jurisdictional claims in published maps and institutional affiliations.

(C) 2020 by the authors. Licensee MDPI, Basel, Switzerland. This article is an open access article distributed under the terms and conditions of the Creative Commons Attribution (CC BY) license (http://creativecommons.org/licenses/by/4.0/). 